\title{
Creating College Opportunity: School Counselors and Their Influence on Postsecondary Enrollment
}

\author{
Andrew S. Belasco
}

Received: 5 October 2012

(C) Springer Science+Business Media New York 2013

\begin{abstract}
School counselors are the primary facilitators of college transition for many students, yet little is known about their influence on college-going behavior. Analyzing data from the Educational Longitudinal Study of 2002, this study employs coarsened exact matching and multilevel modeling to examine the effects of student-counselor visits on postsecondary enrollment, as well as determine whether the effects of such visits vary by socioeconomic background. Results suggest that visiting a counselor for college entrance information has a positive and significant influence on students' likelihood of postsecondary enrollment, and that counseling-related effects are greatest for students with low socioeconomic status.
\end{abstract}

Keywords School counseling · Postsecondary enrollment - Low-SES - Coarsened exact matching

Over the past several decades, the United States has allocated substantial effort to improving college participation. And although policymakers, educators and other stakeholders have succeeded in increasing the number of students who enroll in postsecondary education, significant gaps still remain. For example, students with at least one collegeeducated parent enroll in postsecondary education at nearly twice the rate of students whose parents do not possess a college degree (Aud et al. 2011), while high-income students in the lowest standardized test quartile enroll in college more frequently than lowincome students in the highest test quartile (Carnevale and Strohl 2010). Other analyses show that even when economically and/or socially disadvantaged students students do enroll, they do so at lower priced and less selective institutions, where resources are comparatively scarce and graduation rates are comparatively low (Carnevale and Strohl 2010; Thomas and Perna 2004).

Traditionally, researchers have attributed inequities in college access to the lack of financial resources and academic preparation among many students with low

A. S. Belasco $(\square)$

Institute of Higher Education, University of Georgia, Meigs Hall, Athens, GA 30602, USA

e-mail: abelasco@uga.edu 
socioeconomic status (Adelman 2006; Heller 1999; St. John 2003). More recently, however, researchers have called attention to the insufficient and/or inaccurate information that a number of low-SES students have with respect to college admissions and financial aid (Bettinger et al. 2009; Perna 2006; Tierney and Venegas 2009). Several studies, for instance, reveal that low-SES students are more likely to overestimate college costs, underestimate the availability of financial aid, and exhibit poor knowledge about the academic prerequisites to college attendance (Avery and Kane 2004; Deil-Amen and Tevis 2010; Grodsky and Jones 2004; Horn, Chen and Chapman 2003). Unforunately, collegerelated disparities between low-SES students and their more advantage counterparts are often exacerbated by the conditions in which low-SES students reside. McDonough (1997) and Perna (2006), for example, assert that the availability of college information is closely tied to socioeconomic environment, and that low-SES students are unlikely to have adequate access to individuals within their homes or communities who can transmit college knowledge and promote college enrollment. As a result, many low-SES students are driven to rely on their respective schools for college-related support (Venezia et al. 2003).

Currently, there is no school professional more important to improving college knowledge than the high school counselor (McDonough 2005). This is especially so in the case of disadvantaged populations, as students and parents with low socioeconomic status learn most via their involvement with a counselor (Kim and Schneider 2005; Plank and Jordan 2001). Prior research suggests that school counselors facilitate college participation by encouraging college aspirations (Holcomb-McCoy 2010); aiding students' academic preparation (Brown and Trusty 2005); guiding students through the college application process (Bryan et al. 2011); elucidating parents' role in college planning (Rowan-Kenyon et al. 2008); and ensuring that schools possess and pursue a college mission (McDonough 1997).

While previous studies support a positive relationship between school counseling and college planning, many students attend schools where they do not have sufficient access to a counselor. NCES (2009) reports a national student-to-counselor ratio of 457 to 1 , and ratios are often highest "in schools where students are facing the greatest economic challenges" (Bridgeland and Bruce 2011, p. 20).

The increasingly multifarious role of the school counseling profession also presents obstacles. Venezia and Kirst (2005) reveal that school counselors now spend the majority of their time addressing the various emotional and administrative needs of students, and are increasingly assigned to job tasks that are inappropriate or unrelated to their designated professional role. As a consequence, many counselors have little time for postsecondary planning. Clinedinst et al. (2011), for example, find that public school counselors devote only $23 \%$ of their time to postsecondary counseling, on average, while McDonough (2005) estimates that the average counselor currently spends only 38 minutes per year advising each student on college-related matters, which is, presumably, far less than the amount of time required to provide sufficient and adequate college guidance, especially to students coming from families and backgrounds where college-going is not the norm.

Despite some evidence documenting the ability of school counselors to promote college knowledge, and more compelling evidence revealing the lack of college counseling in many U.S. high schools, little research has been devoted to exploring the relationship between student-to-counselor interaction and college participation. As such, the following study attempts to analyze the influence of school counseling on postsecondary enrollment, for low-SES students especially, as their improved educational attainment is critical to meeting America's future education and workforce needs (Lee et al. 2011). Specifically, I use nationally representative data from NCES's Education Longitudinal Study of 2002 to 
examine whether visiting a school counselor for college-related information affects the likelihood of two postsecondary-related outcomes: (1) enrollment in postsecondary education in general; and (2) enrollment at four-year institutions in particular. Ultimately, this study aims to empirically validate prior research describing the positive influence that school counselors may have on the postsecondary trajectories of students.

\section{Theory and Evidence}

There are several existing theoretical frameworks within which to analyze postsecondary enrollment behavior and the influence that school counselors may have on low-SES students. Each contributes important but partial understanding of the role that school-based counselors play in the college planning process. Consistent with the most current research on the relationship between high school context and college access (Engberg and Wolniak 2010; Rowan-Kenyon et al. 2011), this study is guided by theories of both human and social capital.

From an economic standpoint, human capital theory promotes our understanding of postsecondary choice by framing the decision to attend college as one that is based on productivity improvement and potential investment returns (Becker 1993). Generally, it predicts that students with more financial resources and academic preparation will be more likely to enroll in postsecondary education (Catsiapis 1987). However, human capital models also suggest that postsecondary choice is not strictly dependent upon accumulated assets or competencies-individuals' choices of whether and where to attend college will also vary according to the context within which they make their college-related decisions. For example, Desjardins and Toutkoushian (2005), as well as other economic theorists (Becker 1993; Elwood and Kane 2000; Paulsen 2001), insist that decisions about education can also be attributed to personal preferences that derive from the attributes or circumstances that shape how individuals perceive the utility of a postsecondary education - such as prior knowledge about college, access to college-related information, and educationrelated goals.

Although human capital theory illuminates the influence of preferences on postsecondary enrollment and choice, it does not attempt to explain how individuals arrive at such preferences (DesJardins and Toutkoushian 2005; Perna 2006). Presumably, narrowing the college access gap requires an understanding of how and why students make the postsecondary-related decisions that they make. To make sense of such a process, it is necessary to rely on additional theoretical constructs, namely those which provide insight into the antecedents and determinants of individual choice and behavior. The social capital framework provides one such construct.

Coleman (1988), for example, explains that social capital gives rise to the information flows that facilitate opportunity and material gain. In the case of postsecondary attainment, information is paramount; without information, students cannot navigate and subsequently meet college entry and graduation requirements. While students of high socioeconomic status can look to their primary source of social capital, the family unit, for information about college (Perna and Titus 2005), low-SES students usually do not have such a luxury. Perna (2004) insists that most low-SES families want to help further their child's education, but their ability to do so is hampered a relative lack of knowledge and experience with respect to college, as well as various economic and psychological barriers.

Bourdieu and Passeron (1977) argue that the consistent and growing constraints less advantaged students face in their efforts to access postsecondary education are eventually 
absorbed and reflected in habitus - a system of internalized and enduring dispositions toward "practical" and "appropriate" action (Bourdieu and Wacquant 1992; McDonough 1997). Ultimately, habitus dictates what is possible for a particular individual (Horvat 2001)—providing a "filter that implicitly determines what a student 'sees"” (Paulsen and St. John 2002, p. 196). In the context of postsecondary choice, habitus determines and structures the set of prospective colleges that students perceive as suitable or realistic (Paulsen and St. John 2002). It also generates social-class-based strategies for securing desired and "acceptable" college choice outcomes (McDonough 1997). For economically advantaged students, this usually includes commencing the college search process early in one's high school career, remediating relative weaknesses in certain academic areas, building a college admissions profile through extensive extracurricular involvement, enrolling in test-prep courses, and even hiring a private college admissions counselor (McDonough et al. 1997). While habitus works to strengthen the aspirations and credentials of middle-to-upper class students, it often limits the opportunities of less advantaged populations. For example, Lamont and Lareau (1988) explain that students with insufficient social capital may lower their postsecondary aspirations or self-select out of college altogether because they are unfamiliar and/or uncomfortable with college-going norms. Their findings are substantiated by later research showing that many low -SES students fail to secure the credentials and financial aid needed for college, in large part, because they feel estranged from the individuals and activities that facilitate postsecondary access and success (Luna De La Rosa 2006).

Despite the phenomenal and material barriers imposed upon individuals with low socioeconomic status, upward mobility is still possible. This is especially so in the case of socioeconomically disadvantaged youth — and in the context of postsecondary access (Stanton-Salazar and Dornbusch 1995). Disadvantaged students, for example, may capitalize upon the expertise of institutional agents within their respective schools-such as counselors - who can provide information and assistance with respect to college planning. In this context, school-based counselors represent what Lin (2001) and others refer to as "weak ties." According to Granovetter (1973), weak ties are mere acquaintances, yet serve as a bridge to other social networks normally beyond the reach of an individual-providing access to information and resources different from that provided by one's own network, and which make possible certain activities that were previously unimagined or considered improbable (Granovetter 1983). A primary source of college-related information for lowSES students and their parents (Rowan-Kenyon et al. 2008), school counselors also exert a positive influence on the academic achievement, college aspirations, and college readiness of low-SES populations (Adelman 2006; Freeman 1997; McDonough 2005; Muhammad 2008). Consequently, they fulfill a "weak-tie" role by providing low-SES students with the human and social capital needed to prepare for, and transition into, postsecondary education, and which would otherwise be unavailable (Kim and Schneider 2005; McDonough 2005; Plank and Jordan 2001). While many low-SES families are unable to rely on their immediate social networks for advice or help regarding high school course selection, financial aid application or institutional choice, they may be able to refer to their school counselor for assistance on these and other such college-related matters-at least in theory.

Although theory suggests that school counselors can increase college access, research documenting their impact on postsecondary enrollment specifically is still quite scant. Only a few studies endeavor to examine whether and how counselors improve postsecondary attendance. King's (1996) descriptive study, for example, found that low-income students were more likely to attend a four-year college if they frequently met with a school counselor who encouraged and supported their attempts to enroll in college. Plank and 
Jordan's (2001) study yielded similar results, and showed that students receiving "guidance and help from school" were significantly more likely to attend four-year institutions. However, it is important to note that the variable Plank and Jordan used to measure "guidance and help" did not explicitly cite school counselors as the only or even main source of such help.

Additional research shows that counselors indirectly affect the likelihood of postsecondary attendance. For example, both McDonough (1997) and Hossler et al. (1999) found that counselors influenced students' college-related plans through parent interaction and, in particular, by providing parents with college-related information and support. In addition, Lapan et al. (1997) discovered that students attending high schools with fully implemented guidance counseling programs earned higher grades and received more college-related information-both of which helped to improve their chances of enrolling and persisting in postsecondary education. Finally, Bryan et al. (2011) uncovered a positive relationship between school counseling and college application, a necessary and important precursor to college enrollment.

\section{Research Questions}

Although the above cited studies provide support for school-based college counseling, none examined - through appropriate statistical methods-whether school counselors, in particular, affected postsecondary enrollment specifically. Therefore, this study aimed to assess the relationship between school-based counseling and the likelihood of postsecondary attendance, particularly, by addressing the following two research questions:

(1) To what extent do students who visit their school counselor for college-related information have a greater likelihood of enrolling in postsecondary education, and at four-year institutions in particular?

(2) To what extent does the influence of school-based college counseling vary by socioeconomic status?

\section{Methods}

Data and Sample

To answer the above research questions, I relied on data provided by the Educational Longitudinal Study of 2002 (ELS). From 2002 to 2006, NCES used ELS to biennially track the educational progress and transitions of a nationally representative sample of tenth grade students. In addition to including student-level data on academic performance, socioeconomic background, and postsecondary enrollment status, ELS also includes information on the high school experiences of respondents-particularly, and most pertinent to this study-their use of high school counseling services. The initial sample for this study included all ELS respondents—approximately 16,100 in total. ${ }^{1}$ I then removed from the initial sample respondents who did not compare to at least one other respondent on several

\footnotetext{
${ }^{1}$ As explained below in the Analytic Design subsection, I employed full information maximum likelihood estimation, which allowed for the incorporation of all cases with data on at least one variable included in my model.
} 
covariates that are likely to predict receipt of school-based college counseling. ${ }^{2}$ The final analytic sample for this study included 11,260 students from one of 750 schools, and after weighting, represented 2,679,049 students attending approximately 23,500 high schools across the United States.

\section{Variables}

The dependent variable used in this study was categorical and indicated the institutional level of the first college or university students attended as of 2006, the year immediately after respondents were presumed to have graduated from their respective high schools. The original ELS variable was then re-categorized and respondents were classified as having enrolled at a four-year institution, a two-year institution, or as having not enrolled in postsecondary education.

Independent covariates incorporated into the analysis correspond to the theoretical perspectives discussed above, which highlight the importance of both human and social capital to postsecondary enrollment and choice. They included demographic and socioeconomic characteristics ${ }^{3}$ (Hearn 1991; McDonough 1997; Walpole, 2003), academic achievement and ability as measured by respondents' high school GPA (grades 9 through 12) and standardized assessment scores $^{4}$ (Adelman 2006; Alon and Tienda 2007), curricular intensity as indicated by the highest math course that respondents have completed ${ }^{5}$ (Attewell and Domina 2008; Martinez and Klopott 2005), and postsecondary expectations (Choy 2001; Glick and White 2004; Hossler and Gallagher 1987).

In addition to student-level factors, I also accounted for elements of school context that, according to prior research, promote human and social capital and influence the collegegoing behavior of students, namely school control (Coleman and Hoffer 1987), student-toteacher ratio (Hill 2008), the percentage of each school's graduates attending four-year colleges and universities (Engberg and Wolniak 2010), and a measure indicating the average SES of a school's attendees (McDonough 1997).

My primary independent variable (i.e., my variable of interest) was categorical and derived from two dichotomous variables featured in the ELS study, one of which indicated whether students visited their counselor for college-related information in tenth grade and the other of which indicated whether students visited their counselor for college-related information in twelfth grade. ELS students were categorized as having visited their counselor in both grades, one grade only, or never.

Finally, this study incorporated one interaction term to examine variations in counselor "effects" by socioeconomic status, and to determine whether low-SES students do indeed benefit most from their involvement with a school counselor, as prior research has suggested (Kim and Schneider 2005; Plank and Jordan 2001).

\footnotetext{
${ }^{2}$ See discussion on coarsened exact matching in the Analytic Design subsection.

${ }^{3}$ Socioeconomic status is measured by a composite variable featured in ELS:2002/2006 and other NCES large-scale studies, and that is based on five equally weighted components of information provided by students' parents via ELS's base year (2002) parent questionnaire: father's education; mother's education; family income; father's occupation; and mother's occupation. The SES composite variable is continuous, with higher calculated student SES scores assigned to students of higher socioeconomic status.

${ }^{4}$ Scores are from a math and reading standardized assessment administered by NCES during the base year (2002) of the ELS survey.

${ }^{5}$ Math course-taking, in particular, has been identified as the strongest predictor of success in college (Adelman 2006; Conley 2005; Zelkowski 2010), and also shapes the postsecondary-related decision making of students (Eccles et al. 2004; Zeldin et al. 2008).
} 
Analytic Design

To "tease out" the effect of my primary independent variable, it was necessary to consider the possible endogeneity of counselor visitations. Most likely, unobservable factors that affected a student's decision to visit a counselor for college-related information also influenced his or her decision to enroll in postsecondary education. For example, it is likely that students with greater motivation or family support were more inclined to attend college and visit with their counselor. If I did not account for the probable correlation between these two postsecondary-related outcomes, any effects attributed to counselor visitations may have been spurious (Greene 2011), and may have been the result of unobserved characteristics and/or circumstances that moved one to enroll in postsecondary education. Therfore, to reduce the bias associated with my estimates, I strived to control for students' propensity to obtain school-based college counseling, in particular, by employing coarsened exact matching (Iacus et al. 2012).

Coarsened exact matching (CEM) is a relatively new, non-parametric technique that controls for the confounding influence pretreatment variables may have on the ability to produce unbiased effect estimates, specifically by reducing a sample to include only observations that compare on characteristics predictive of a treatment or intervention. Like other more popular matching methods, CEM strives to establish covariate balance between treated and control units (i.e., observations). However, CEM is distinctive in that it does not require the researcher to construct a matching algorithm; instead CEM temporarily coarsens each $k$ treatment-related variable into $m$ substantively meaningful categories (the number of which is determined by the researcher and which is based on previously established theory and/or practice) and assigns units into one of $k_{m 1} \times k_{m 2} \times \ldots k_{m n}$ strata, each of which is weighted according to the number of treated and control units it contains. Observations within strata that do not contain at least one treated and control unit are zeroweighted and set aside, while observations within "matched" strata are subsequently uncoarsened and passed on for post-matching analysis. The cycle of coarsening and un-coarsening upon which CEM relies enables users to avoid the "curse of dimensionality" that effectively renders exact matching algorithms obsolete (Blackwell et al. 2009).

After CEM removes unmatched (i.e., incomparable) observations and a "matched" sample is produced, users apply statistical models to estimate the effect of a particular treatment-in this case, counseling: $T E_{i}=Y_{i}(1)-Y_{i}(0)$, where $Y_{i}(1)$ is the postsecondary enrollment status of an ELS respondent if he/she receives the counseling "treatment" and where $Y_{i}(0)$ is the postsecondary enrollment status of the same ELS respondent if he/she does not receive treatment. However, since the actual treatment effect is unobserved (observations either receive or do not receive treatment) and varies across units, CEM and other matching techniques instead strive to estimate the sample average treatment effect on the treated (SATT) (Blackwell et al. 2009):

$$
S A T T=\frac{1}{n_{T}} \sum_{i \in T} T E_{i}
$$

In the context of this study, CEM enabled comparisons between counselees and noncounselees of similar backgrounds, academic records, postsecondary expectations and school environment, and who given their shared pre-treatment, observed characteristics, were likely to compare on unobserved characteristics that predict both treatment and outcome. While other matching techniques, like those using propensity scores (PSM) or Mahalanobis distances (MD), also strive to achieve comparability between treated and 
untreated units, they do not offer the same statistical and methodological advantages that CEM offers.

For example, in contrast to other matching techniques, CEM allows users to set, ex ante, the bounds within which matched comparisons are to be made, and consequently, to define the amount of covariate imbalance they are willing to tolerate. This makes certain that users restrict their analyses to a region of common empirical support and that they do not extrapolate beyond the comparable range of their data. ${ }^{6}$ In addition, CEM also allows users to analyze and improve balance for each variable in isolation, a procedure that is commonly referred to as Monotonic Imbalance Bounding (MIB) and which offer users a clear and decidedly effective course through which to reduce the statistical bias associated with their estimates (Iacus et al. 2012). ${ }^{7}$ Finally, since CEM operates within sample space and in the data space where $\mathbf{X}$ is generated, users can make robust inferences without assuming anything about the data generating process. $^{8}$

In their seminal paper on MIB, Iacus et al. (2011) show that CEM outperforms PSM, MD and other matching methods in reducing covariate imbalance, model dependency, estimation error and estimation variance. Consequently, and given its sound statistical properties, CEM has become an increasingly popular technique within many social science disciplines, and deserves greater attention from researchers within the field of education. While CEM is not a panacea for the deficiencies of observational studies-CEM (or any other matching technique) rarely produces a complete and perfectly matched sample, so covariates must still be incorporated into one's analytical model to control for remaining differences - if done correctly, it can reduce (not eliminate) estimation bias. Ideally, CEM allows users to compare "apples with apples" - if not of the same shape, at least of the same color.

Table 1 compares counselees and non-counselees on the variables included in my study, both before and after matching, and highlights the extent to which CEM improved covariate balance among the "treated" and control units within my sample.

\footnotetext{
${ }^{6}$ In contrast, PSM relies on model based procedures (usually a logit or probit function) and matches units that share similar scores, but that may also differ considerably one or more covariates included in the model - since units are matched on predicted probabilities of treatment, and not on their actual traits. PSM may also produce scores that incorporate observations existing within a region or sample space of extrapolation (i.e., propensity scores may be tainted by treated observations that do not contain a control counterpart, and vice versa). In both instances, estimates of a treatment effect are likely to be biased (Battistin and Chesher 2004).

${ }^{7}$ Other matching methods that are not MIB (e.g., PSM and MD) are designed to address a different and less concerning problem, namely large variance. However, attempts to maximize efficiency (via ensuring an adequately sized sample) often preclude users from achieving a desired level of covariate balance. This tradeoff is unfavorable, given that sample sizes are sufficiently large in many observational studies, particularly those which are conducive to matching, and also given that "it is generally not wise to obtain a very precise estimate of a drastically wrong quantity" (Rubin 2006, p. 11). For example, in empirical applications, researchers often have to tweak and rerun PSM and Mahalanobis models to produce an accepted level of balance; however, model specifications that improve balance on one variable may reduce balance on another, leaving researchers guessing as to which matching algorithm produces the least bias. In contrast, CEM's non-parametric properties enable researchers to define the value space within which units are to be matched-for each covariate separately and without influencing balance in any of the other included covariates-in effect, producing greater global balance, and consequently, less bias.

${ }^{8}$ However, since PSM and Mahalanobis methods are model dependent (in that they reduce a covariate set from $k$-dimensional space to a more restricted space defined by a propensity score or Mahalanobis distance) causal inference is justifiable only under a certain set of unverifiable assumptions, namely that one's model is correctly specified, of a correct functional form, and that propensity scores are constant across $\mathbf{X}$ (Iacus and King 2012). These assumptions often impose and insurmountable burden of proof upon a researcher who is attempting to defend the quasi-experimental design of his or her study.
} 
Table 1 Weighted means for variables: counselees vs. non-counselees

\begin{tabular}{|c|c|c|c|c|c|c|c|c|}
\hline \multirow[t]{2}{*}{ Variable } & \multirow[t]{2}{*}{ Min } & \multirow[t]{2}{*}{$\operatorname{Max}$} & \multicolumn{3}{|c|}{ All ELS respondents } & \multicolumn{3}{|c|}{ Matched respondents } \\
\hline & & & $\begin{array}{l}\text { Visit } \\
\text { (none) }\end{array}$ & $\begin{array}{l}\text { Visit } \\
\text { (one) }\end{array}$ & $\begin{array}{l}\text { Visit } \\
\text { (both) }\end{array}$ & $\begin{array}{l}\text { Visit } \\
\text { (none) }\end{array}$ & $\begin{array}{l}\text { Visit } \\
\text { (one) }\end{array}$ & $\begin{array}{l}\text { Visit } \\
\text { (both) }\end{array}$ \\
\hline \multicolumn{9}{|l|}{ Student level } \\
\hline SES & -2.11 & 1.98 & -0.142 & 0.044 & 0.156 & 0.160 & 0.175 & 0.222 \\
\hline Asian & 0 & 1 & 0.030 & 0.040 & 0.049 & 0.040 & 0.044 & 0.051 \\
\hline Black & 0 & 1 & 0.146 & 0.139 & 0.121 & 0.101 & 0.126 & 0.098 \\
\hline Latino & 0 & 1 & 0.188 & 0.140 & 0.113 & 0.119 & 0.123 & 0.099 \\
\hline Other & 0 & 1 & 0.061 & 0.052 & 0.048 & 0.061 & 0.054 & 0.050 \\
\hline White & 0 & 1 & 0.575 & 0.629 & 0.670 & 0.679 & 0.654 & 0.703 \\
\hline Female & 0 & 1 & 0.443 & 0.521 & 0.571 & 0.562 & 0.520 & 0.582 \\
\hline Expectations $^{\mathrm{a}}$ & 0 & 2 & 0.918 & 1.294 & 1.468 & 1.369 & 1.294 & 1.419 \\
\hline GPA & 0 & 4 & 2.248 & 2.656 & 2.879 & 2.803 & 2.796 & 2.876 \\
\hline Tested Ability & 20.91 & 81.04 & 47.541 & 51.458 & 53.956 & 52.090 & 51.745 & 54.355 \\
\hline Math Level $^{\mathrm{b}}$ & 0 & 2 & 0.863 & 1.230 & 1.434 & 1.148 & 1.118 & 1.280 \\
\hline \multicolumn{9}{|l|}{ School level } \\
\hline Private Control & 1 & 2 & 1.190 & 1.119 & 1.200 & 1.082 & 1.078 & 1.091 \\
\hline $\begin{array}{l}\text { School SES } \\
\text { (Mean) }\end{array}$ & - & 1.439 & -0.092 & 0.012 & 0.028 & -0.001 & 0.014 & 0.022 \\
\hline$\%$ Four-Year $^{\mathrm{c}}$ & 1 & 4 & 2.303 & 2.569 & 2.596 & 2.454 & 2.428 & 2.533 \\
\hline $\begin{array}{l}\text { Student-Teach. } \\
\text { Ratio }\end{array}$ & 4.65 & 54.17 & 15.311 & 14.769 & 15.073 & 14.762 & 14.741 & 14.980 \\
\hline $\mathrm{N}$ & & & 4,850 & 6,440 & 3,470 & 3,190 & 4,720 & 2,800 \\
\hline $\mathrm{N}$ (weighted) & & & 971,518 & $1,324,477$ & 719,287 & 917,707 & $1,109,449$ & 614,474 \\
\hline
\end{tabular}

a $0=$ less than a four-year degree; 1 = four-year degree; 2 = graduate degree

b $0=$ less than Algebra II; $1=$ Algebra II; $2=$ Trigonometry or higher

c $1=0-24 \% ; 2=25-49 \% ; 3=50-74 \% ; 4=75-100 \%$

After preprocessing my data via CEM, I used a generalized linear model with a random intercept to identify significant student- and school-based predictors of postsecondary enrollment, and to increase the efficiency of my parameter estimates (Luke 2004; Raudenbush and Bryk 2002). The generalized linear model I incorporated into my study employed a multinomial logit link function-which is suitable for estimating categorical outcomes (Hosmer and Lemeshow 1989) and for the study of postsecondary enrollment (Cabrera 1994) - to distinguish between the differing influence counseling may have on "two-year" enrollment and "four-year" enrollment, respectively. This distinction is important, given the varying academic and professional pathways of "two-year" and "four-year" students, and also because I anticipated that counselor visitations would be more positively and strongly related to "four-year" enrollment, given that the application process at four-year institutions is significantly more rigorous than that at two-year colleges, and requires significantly more work on the part of both student and counselor.

Formally, the two-level, multinomial model can be expressed as:

$$
\begin{aligned}
\eta_{m i j} & =\mu_{j}+\alpha(\text { Counselor Visits })_{i j}+\beta(\mathrm{SES})_{i j}+\delta(\text { Counselor Visits } * \mathrm{SES})_{i j}+\gamma \mathbf{X}_{i j}+\epsilon_{i j} \\
\mu_{j} & =\mu+\gamma \mathbf{X}_{j}+\epsilon_{j}
\end{aligned}
$$


where $\eta_{m i j}$ is the log odds of particular enrollment outcome, compared to the log odds of the base outcome in the model $\pi_{m i J}$, no enrollment in postsecondary education; $\mu_{j}$ indicates the random intercepts that vary over high school $j ; \alpha_{i j}$ and $\beta_{i j}$ represent individual-level effects for counselor visits (regarding college) and SES, respectively; $\delta$ interacts the variables for counselor visits and SES, and indicates whether the effects of school-based college counseling vary by socioeconomic status; and $\mathbf{X}_{i j}$ and $\mathbf{X}_{j}$ are vectors of individualand school-level covariates, respectively.

For the above model to yield accurate results, I was compelled to adopt an estimation or ad hoc procedure that accounted for missing data in my sample. Estimating my model without accounting for missingness within ELS would have resulted in the deletion of nearly $20 \%$ of my analytic sample. According to Allison (2002), complete case methods (i.e., methods incorporating listwise deletion) that substantially reduce sample size are likely to produce bias parameter estimates. Therefore, assuming data are missing at random (MAR), and according to current methodological research, I had the option of employing either multiple imputation (MI) or full-information maximum likelihood (FIML) to correct for the bias that was likely to result from complete case analysis-both approaches are considered current "state of the art" (Schafer and Graham 2002).

Provided certain assumptions, namely that my data are distributed multivariate normal ${ }^{9}$ and are not missing not at random (MNAR) (i.e., the probability of missingness on $\mathbf{Y}$ is related to $\mathbf{Y}$ itself), both MI and FIML yield consistent, asymptotically normal and efficient estimates. However, the validity of MI also assumes that imputation models are correctly specified and are "congenial" with subsequent analytical models (e.g., analytical models that include interaction terms or transformed variables must rely on imputation models that include the same interactions/transformations) (Rubin 1996; Treiman 2009). Unfortunately, both assumptions are easily and quite frequently violated in practical applications (Allison 2000). As such, FIML is increasingly becoming a preferred method of choice for handling missing data (Allison 2012; Baraldi and Enders 2010; Raykov and Marcoulides 2010) and it is the missing data approach that I chose to adopt in this study.

In FIML, estimation is based on all observed data. More specifically, it relies on a reduced form of the multivariate distribution for cases with missing data, thereby allowing all cases (with at least one data point) to contribute to the maximum likelihood function. ${ }^{10}$

\footnotetext{
${ }^{9}$ It is important to note that while the normal distribution plays an essential role in maximum likelihood estimation, FIML is quite robust in the presence of non-normal data (Enders 2001). However, in models with highly discrete dependent variables, such as the one used in this study, FIML may lead to bias standard errors. As a corrective measure, and based on the recommendation of Enders (Enders 2010), I incorporate a robust estimator (White 1980) into my analysis.

${ }^{10}$ Put more explicitly, and to utilize an example from Peugh and Enders (2004), suppose our objective is to estimate a covariance matrix and vector of means used to provide regression estimates. In order to do so, the FIML estimator maximizes the following log-likelihood function for each observation in a particular sample:

$\log L_{i}=K_{i}-\frac{1}{2} \log \left|\Sigma_{i}\right|-\frac{1}{2}\left(x_{i}-\mu_{i}\right)^{\top} \Sigma^{-1}\left(x_{i}-\mu_{i}\right)$

where $K_{i}$ is a constant indicating the number of complete data points for observation $i, x_{i}$ is the observed data for observation $i ; \mu_{i}$ and $\Sigma_{i}$ are parameter estimates for the mean vector and covariance matrix, respectively, and the size of which are determined by the number of variables on which a particular observation has complete data, as denoted by the subscripts $i$ in the above equation. The likelihood functions for each observation are then summed across the entire sample and maximized according to the following:
}

$\log L(\mu, \Sigma)=\sum_{i=1}^{N} \log L_{i}$ 
For example, in a case where the objective is to predict standardized test scores as a function of gender, race, and high school GPA, observations (i.e., students) with complete data contribute the following case-specific arrays into the sample log-likelihood function:

$$
\begin{aligned}
& \mathrm{X}_{\mathrm{i}}=\left[\begin{array}{lll}
X_{i, \mathrm{Gender}} & X_{i, \text { Race }} & X_{i, \mathrm{GPA}}
\end{array}\right] ; \mu_{\mathrm{i}}=\left[\begin{array}{c}
\mu_{\mathrm{Gender}} \\
\mu_{\text {Race }} \\
\mu_{\mathrm{GPA}}
\end{array}\right] ; \\
& \Sigma_{\mathrm{i}}=\left[\begin{array}{ccc}
\sigma_{\text {Gender }}^{2} & \sigma_{\mathrm{Gender}, \text { Race }} & \sigma_{\mathrm{Gender}, \mathrm{GPA}} \\
\sigma_{\text {Race,Gender }} & \sigma_{\text {Race }}^{2} & \sigma_{\text {Race,GPA }} \\
\sigma_{\mathrm{GPA}, \text { Gender }} & \sigma_{\mathrm{GPA}, \mathrm{Race}} & \sigma_{\mathrm{GPA}}^{2}
\end{array}\right]
\end{aligned}
$$

Whereas observations with missing data on high school GPA, for instance, contribute a reduced variation of the above, allowing FIML to use all available data for parameter estimation: ${ }^{11}$

$$
\mathrm{X}_{\mathrm{i}}=\left[\begin{array}{ll}
X_{i, \text { Gender }} & X_{i, \text { Race }}
\end{array}\right] ; \mu_{\mathrm{i}}=\left[\begin{array}{c}
\mu_{\text {Gender }} \\
\mu_{\text {Race }}
\end{array}\right] ; \Sigma_{\mathrm{i}}=\left[\begin{array}{cc}
\sigma_{\text {Gender }}^{2} & \sigma_{\text {Gender,Race }} \\
\sigma_{\text {Race,Gender }} & \sigma_{\text {Race }}^{2}
\end{array}\right]
$$

In addition to accounting for missing data, I was also compelled to account for the complex and multistage sampling procedures used to generate the ELS data; otherwise my model was likely to yield underestimated standard errors (Thomas and Heck 2001). I therefore incorporated variables indicating the stratum and cluster to which each observation belonged, as well as student-level and school-level sampling weights, the former of which were scaled to improve the efficiency of my estimates (Rabe-Hesketh and Skrondal 2006).

After controlling for missing data and for the complexity of the ELS sample, I estimated my model and analyzed the resulting multinomial coefficients to assess whether student-counselor visits had a positive and significant influence on enrollment at two-year and four-year institutions. Given a significant interaction effect between counselor visits and socioeconomic status, I also analyzed linear combinations of my main-effect and interaction terms to determine at which levels of socioeconomic status the effects of counseling were significant and at their greatest. Finally, using Stata's cmp program (Roodman 2011), I generated out-of-sample predictions to compare the probability of postsecondary enrollment among students who possessed similar SES scores, but different values on the counselor-visit indicator.

\section{Limitations}

There are several limitations of potential consequence in this study, which relate to my sample and model, respectively. First, in the course of matching and in order to ensure that I did not extrapolate beyond the comparable range of my data, I was forced to eliminate

\footnotetext{
${ }^{11}$ Additionally, and perhaps not quite as apparent, all cases, even those with incomplete data, contribute to the estimation of every parameter in the model (Peugh and Enders 2004). For example, in a trivariate model, where $\mathbf{X}$ and $\mathbf{Y}$ predict $\mathbf{Z}$, observations with $\mathbf{X}$ and $\mathbf{Y}$, but not $\mathbf{Z}$, still contribute to the estimation of $\mathbf{Z}$, since the estimation of $\mathbf{Z}$ is, in part, a function of the covariance between $\mathbf{X}$ and $\mathbf{Y}$. In other words, likely values of $\mathbf{Z}$ are implied by observed values of $\mathbf{X}$ and $\mathbf{Y}$; so, even if observations are missing values on $\mathbf{Z}$, their values of $\mathbf{X}$ and $\mathbf{Y}$ can still contribute to the estimation of $\mathbf{Z}$, while also improving the precision and efficiency of the $\mathbf{Z}$ estimate (since $N$ increases and more information is incorporated into the model). This is conceptually analogous to what occurs during multiple imputation; however, data are not actually imputed in FIML estimation, and so there is no risk of estimating a model on the basis of unlikely values that could have been produced via an improperly specified imputation model.
} 
$16 \%$ of the treated units in my sample. Although constituting a relatively small proportion of the treated sample population, these excluded units precluded me from generalizing my results to the entire sample. In other words, estimates related to counselor visitations (presented below) were indicative of the local SATT and could not be attributed to sample observations for which there were no appropriate matches. To test the sensitivity of my findings, and as recommended by Iacus et al. (2012), I partitioned the treated units that were matched, $m_{t}$, from from the entire population of treated units, $n_{t}$, and then estimated the treatment effect for the unmatched sample via estimating the same generalized linear model that I applied to my matched sample. Finally, I calculated the global SATT estimate as a weighted combination of the two treatment-related coefficients:

$$
\hat{\tau}_{n T}=\frac{\hat{\tau}_{m_{T}} \cdot m_{T}+\hat{\tau}_{n_{T}-m_{T}} \cdot\left(n_{T}-m_{T}\right)}{n_{T}}
$$

where $\hat{\tau}_{m_{T}}$ indicates the estimated effect of my counselor-visit variable for matched, treated units, $m_{T}$ and where $\hat{\tau}_{n_{T}-m_{T}}$ indicates the estimated effect of my counselor-visit variable for unmatched, treated units.

Interestingly, the effect sizes yielded from the above model were actually greater than those generated within the local SATT; however, my substantive findings (discussed below) remained the same.

Despite consistencies between the matched and unmatched treated units in my sample, it is important to note that effect estimates generated from my model may still contain bias, particularly given the data preprocessing and analytic techniques I used, which although appropriate and advantageous, are not perfect. For one, and as indicated previously, CEM and other similar techniques can match only on observed variables. Although matching on background, achievement, ability and expectations should have produced an analytic sample where counselees and non-counselees shared similar unobserved characteristicsunobservable traits like motivation, for instance, are arguably reflected in, and a reflection of, grades, test scores, SES, etc.- - there was not a perfectly reliable way to account (entirely) for influential variables that were not included in the ELS dataset. As such, analyses employing CEM, or matching of any type, may still produce bias effect estimates, and in the context of this study, may have failed to fully distinguish the effects of counseling from the effects of other attributes or circumstances that led one to visit a counselor, but that also moved one to enroll in postsecondary education.

Second, given issues related to non-response, I employed FIML, which relies on the assumption that data are missing at random (MAR). While inclusive analysis strategies (IAS) - in particular, checking for consistency between estimates in my final model and an alternative model including additional, auxiliary variables that were "predictive" of missing values [see Panter and Sterba (2011) for more detail about IAS] —improved the likelihood that my data and analysis exhibited an MAR mechanism, there is no statistical test currently available which can confirm that this was in fact the case (Raykov and Marcoulides 2008). Encouragingly, however, more recent research suggests that MARbased methods, like FIML and MI, do have at least some robustness against violation of the MAR assumption (Enders 2010).

A final limitation associated with my study revolves around the assumption on which my model and all other multinomial models are based. The assumption of independence of irrelevant alternatives (IIA) dictates that multinomial models are appropriate only in the context of independent choice or outcome sets, in which the odds of realizing one outcome, versus another, do not depend on the addition (or subtraction) of another potential outcome. 
For example, in the case of postsecondary enrollment, IIA assumes that the odds of enrolling at a four-year institution, compared with those of enrolling at a two-year institution, will remain the same regardless of whether I remove an alternative outcome from my original outcome set (e.g. no enrollment) or whether I introduce a new potential outcome (e.g., enrollment in the military). Long (1997) cites two statistical tests commonly used to evaluate IIA: Hausman-McFadden (1984) and Small-Hsaio (1985); however, Long and others, like Cheng and Long (2007), reveal that despite being the best available tests of IIA, both Hasuman-McFadden (HM) and Small-Hsiao (SH) exhibit poor statistical properties and "are not useful for assessing violations of the IIA property"(Long and Freese 2006, p. 243). Long proceeds to argue that "the best advice regarding IIA goes back to an earlier statement by McFadden (1973), who wrote that multinomial models should be used only in cases where the alternatives 'can plausibly be assumed to be distinct and weighted independently in the eyes of each decision of each decision maker'" (p. 243). While both HM and SH yield significant test statistics in this study - and may accurately indicate a violation of the IIA property, since recent evidence suggests that many college-qualified students from disadvantaged backgrounds limit their postsecondary choice set to a two-year college or no college at all (Roderick et al. 2009) - I still judged the use of a multinomial model to be appropriate, given that my outcome categories (i.e. enrollment outcomes) are conceptually and practically distinct, and have been treated by higher education researchers as such (Engberg and Wolniak 2010; Hill 2008; Kim and Schneider 2005).

\section{Results}

Table 2 details results from the full multinomial model. Statistical significance is indicated by asterisks next to the coefficients. As expected, variables relating to students' background were significantly associated with the probability of enrolling in postsecondary education. In particular, and in accord with previous research (Walpole 2003), students of higher socioeconomic status were more likely to enroll at two-year and four-year institutions (vs. two-year enrollment and no enrollment) than students of lower socioeconomic status.

Additionally, race was also related to postsecondary attendance. After controlling for other variables that influenced college-going, African-Americans and Hispanics were significantly more likely to enroll at a four-year institution than their White counterpartsa finding that, despite being unanticipated to some, conformed to the findings of more recent studies exploring the relationship between race and college enrollment (GoldrickRab 2006; Turley 2009).

In contrast to race and socioeconomic status, gender did not appear to influence the likelihood of postsecondary enrollment, particularly after other background factors were controlled for. This finding was consistent with other studies suggesting that the gender gap in postsecondary enrollment is not necessarily due to gender itself, but due to other factors that affect how males and females perceive a college education and prepare for the rigors of a postsecondary setting (Beattie 2002; Bozick and DeLuca 2005).

While certain demographics appeared to influence the probability of postsecondary enrollment, the results in Table 2 indicate that academic ability and achievement may have played a greater and more consistent role in determining the postsecondary destinations of students. Students earning higher grade point averages and standardized test scores, and who complete higher-level math courses, were significantly more likely to enroll in postsecondary education and at four-year institutions (vs. no enrollment and enrolling at two-year institutions). These results were unsurprising and supported research previously 
Table 2 Estimating the likelihood of postsecondary enrollment

\begin{tabular}{|c|c|c|c|}
\hline Variable & 2-year vs. none & 4-year vs. none & 4-year vs. 2-year \\
\hline \multicolumn{4}{|l|}{ Student-level variables } \\
\hline \multicolumn{4}{|l|}{ Counselor visit $^{\mathrm{a}}$} \\
\hline One grade & $0.343 * * *$ & $0.594 * * *$ & $0.251^{*}$ \\
\hline Both grades & $0.643 * * *$ & $0.973 * * *$ & $0.331 * *$ \\
\hline \multicolumn{4}{|l|}{ Counselor visit $\times$ SES } \\
\hline One grade $\times$ SES & $-0.341^{*}$ & $-0.460 * *$ & -0.116 \\
\hline Both grades $\times$ SES & $-0.583 * * *$ & $-0.659 * * *$ & -0.133 \\
\hline SES & $0.743 * * *$ & $1.234 * * *$ & $0.488 * * *$ \\
\hline \multicolumn{4}{|l|}{ Race $^{a}$} \\
\hline Black & 0.191 & $1.273 * * *$ & $1.086^{* * *}$ \\
\hline Latino & $0.279^{*}$ & $0.673 * * *$ & $0.392 * *$ \\
\hline Asian & $0.774 * * *$ & $1.044 * * *$ & $0.272 *$ \\
\hline Other & $-0.393 *$ & 0.155 & $0.557 * *$ \\
\hline \multicolumn{4}{|l|}{ Gender $^{\mathrm{a}}$} \\
\hline Female & 0.112 & 0.025 & -0.090 \\
\hline High school GPA & $0.677 * * *$ & $1.528 * * *$ & $0.853 * * *$ \\
\hline Standardized test score & 0.007 & $0.054 * * *$ & $0.047 * * *$ \\
\hline \multicolumn{4}{|l|}{ Math level $^{\mathrm{a}}$} \\
\hline Algebra II & $0.393 * * *$ & $0.778 * * *$ & $0.388 * *$ \\
\hline Trigonometry or higher & $0.389 * * *$ & $1.480 * * *$ & $1.092 * * *$ \\
\hline \multicolumn{4}{|l|}{ Expectations $^{\mathrm{a}}$} \\
\hline Four-year degree & $0.240^{*}$ & $0.797 * * *$ & $0.555^{* * *}$ \\
\hline Graduate degree & $0.434 * * *$ & $1.161 * * *$ & $0.726 * * *$ \\
\hline \multicolumn{4}{|l|}{ School-level variables } \\
\hline \multicolumn{4}{|l|}{ Control $^{\mathrm{a}}$} \\
\hline Private & $0.510 * *$ & $0.498 * *$ & -0.009 \\
\hline Student-to-teacher Ratio & 0.011 & 0.003 & -0.008 \\
\hline Mean SES & $0.351^{*}$ & $0.645^{* * *}$ & $0.303^{*}$ \\
\hline$\%$ attending 4-year colleges & 0.022 & $0.283 * * *$ & $0.261 * * *$ \\
\hline No. of obs. (unweighted) & 11,260 & & \\
\hline Student population (weighted) & $2,679,049$ & & \\
\hline Proportional reduction in error (PRE) & .3302 & & \\
\hline
\end{tabular}

Note From ELS:2002/2006 restricted data

${ }^{a}$ Reference categories in order: Never; White; Male; Less than Algebra II; Less than a four-year degree; Public

$* p<0.05 . * * p<0.01 . * * * p<0.001$

cited in this paper, which demonstrated the strong association between high school performance and postsecondary enrollment.

Like academic performance, student expectations also appeared to have a particularly strong influence on postsecondary enrollment, as students with plans to earn a four-year degree or higher possessed a greater likelihood of enrolling in postsecondary education, and at four-year institutions, than students who expected to earn less than a four-year degree. These results were also anticipated given past research. 
In addition to student-level variables, certain school-level indicators were also related to the likelihood of postsecondary enrollment. In particular, a school's mean socioeconomic status was positively associated with the likelihood of enrolling in postsecondary education and at a four-year institution, as was the percentage of a high school's graduates attending four-year institutions. Attending a private high school also appeared to improve students' likelihood of enrolling at a two-year or four-year institution versus no enrollment specifically. Each of these findings is in accord with the most recent research on the relationship between high school context and postsecondary enrollment (Engberg and Wolniak 2010; Hill 2008).

Surprisingly, a commonly used indicator of academic environment, a school's studentto-teacher ratio, was not significantly related to the likelihood of enrollment-a finding that contradicts Hill (2008), who relied on older data from the National Educational Longitudinal Study (NELS:88-94), but is consistent with the findings of Engberg and Wolniak's (2010) more recent analysis, which also relied on ELS data.

In contrast, student-counselor interaction did exert significant influence on college attendance. As hypothesized, students who visited their counselor for college-related information appear more likely to enroll in postsecondary education and at four year institutions in particular, at least on average. The significant interaction terms in the above table suggests that the influence of school-based college counseling did vary according to socioeconomic background, and that students of lower socioeconomic status may have yielded more benefit from their relationship with a school counselor. Interestingly, Figure 1 shows that effect sizes related to student-counselor visits were greatest for students at lower ends of the socioeconomic scale, and that students of relatively high SES experienced little to no gains in the likelihood of two-year or four-year enrollment as a result of their interactions with a counselor. ${ }^{12}$ Linear hypothesis tests after estimation also showed that low-SES students visiting their counselor in both grades were more likely to enroll at four-year institutions (vs. two year enrollment and no enrollment) than students who visited their counselor in one grade only.

In addition to exhibiting a varying effect on the likelihood of postsecondary enrollment, student-counselor visits also appeared to have a varying effect on the probability of enrollment, though variation was limited to one type of enrollment outcome. Figures 2 and 3 present, respectively, predicted probabilities of enrollment at a four-year institution and anywhere (i.e, at a two- or four-year institution). Probabilities are sorted by socioeconomic status and all variables in the model - except the interaction term and main effect variables for SES and counselor visits - are held constant at their respective means.

As indicated below, Fig. 2 reveals a fairly uniform, yet significant ${ }^{13}$, effect of counseling on the probability of four year enrollment, meaning that the significant interaction term in the four-year enrollment versus no enrollment comparison category was due to a decrease in the probability of no enrollment, rather than an increase in the probability of four-year enrollment, for counselees specifically. ${ }^{14}$

In contrast, Fig. 3 reveals that effect sizes related to postsecondary enrollment anywhere varied considerably, and that low-SES counselees experienced a much larger increase in

\footnotetext{
12 The vertical arrows in each graph indicate at which SES "score" the effect of student counselor visits becomes statistically indistinguishable from zero.

13 Confidence intervals calculated for the predicted probabilities confirm this finding.

14 When discussing results generated by a multinomial model, or other models with a dichotomous or categorical outcome, it is important not to confuse likelihood with probability. For example, and in the context of this study, a significant interaction between student-counselor visits and socioeconomic status indicated varying effect sizes with respect to the odds of one outcome compared to another-for example, four-year enrollment versus no enrollment-but it does not necessarily indicate varying effect sizes with respect to the probability of four-year enrollment overall.
} 

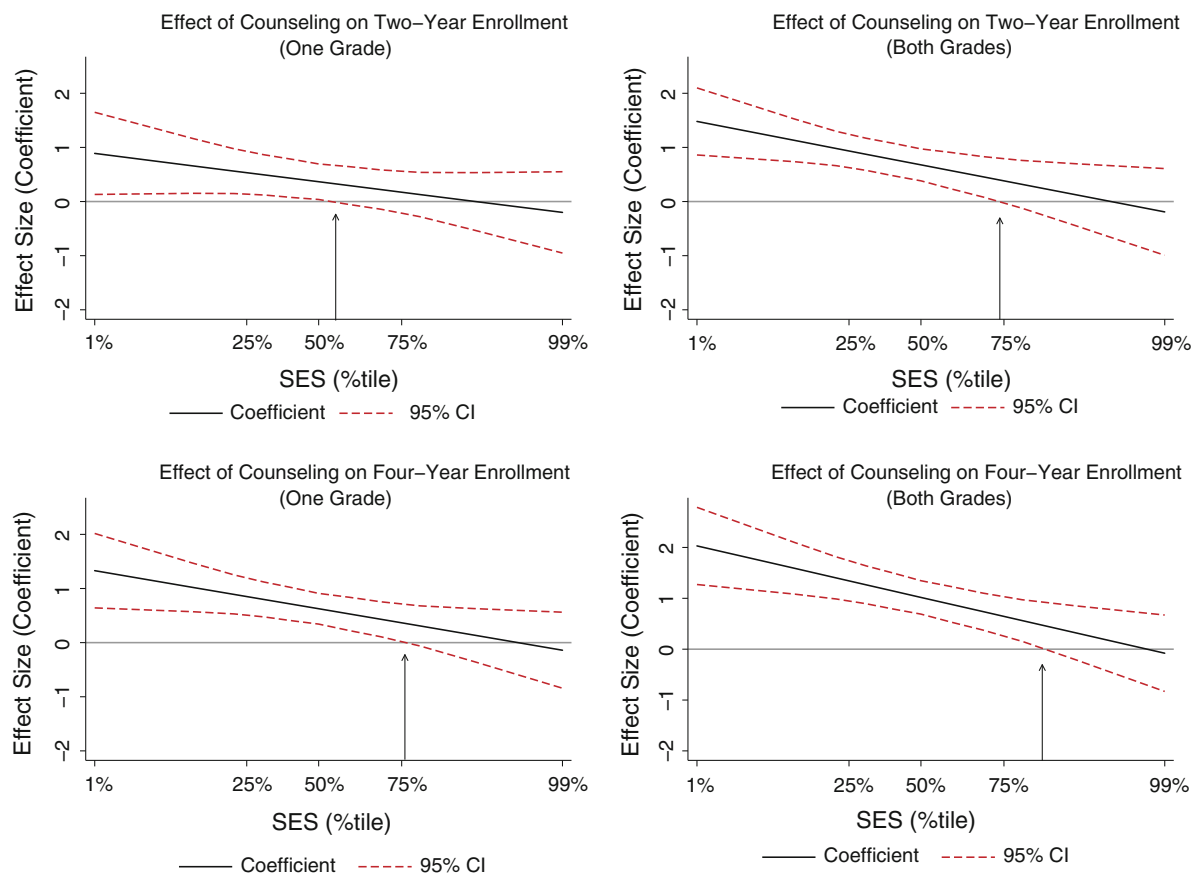

Fig. 1 Effects of counseling by SES

Fig. 2 Probability of four-year enrollment (by SES and visits)

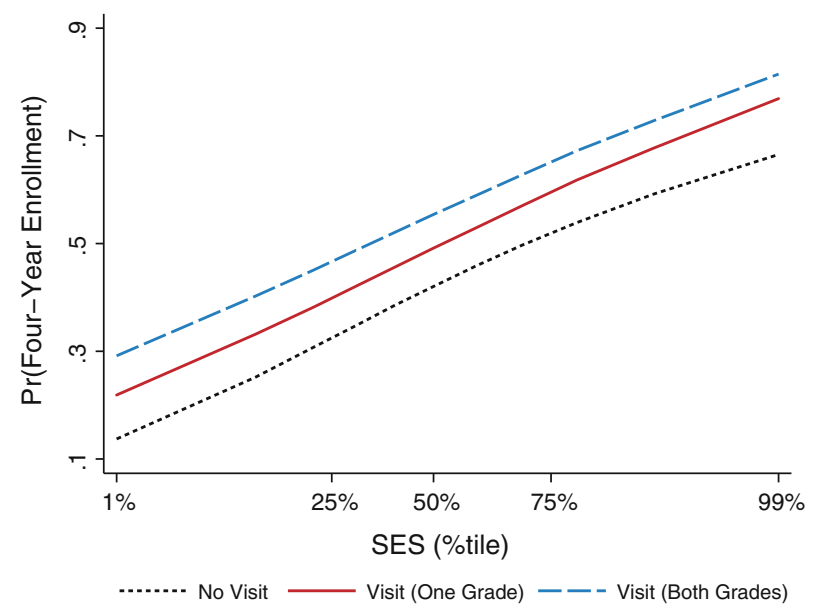

the probability of enrollment—nearly twofold in some instances—than did counselees of higher socioeconomic backgrounds. ${ }^{15}$

\footnotetext{
15 Additionally, and although not pictured in Fig. 3 (to preserve clarity of presentation), it is important to note that confidence intervals for predicted probabilities among counselees and non-counselees begin to overlap between the 35th and 40th percentiles of SES "score", suggesting no significant effects of counselor-visits at higher ends of the socioeconomic scale-at least when it came to the probability of enrolling in postsecondary education anywhere.
} 
Fig. 3 Probability of enrollment anywhere (by SES and visits)

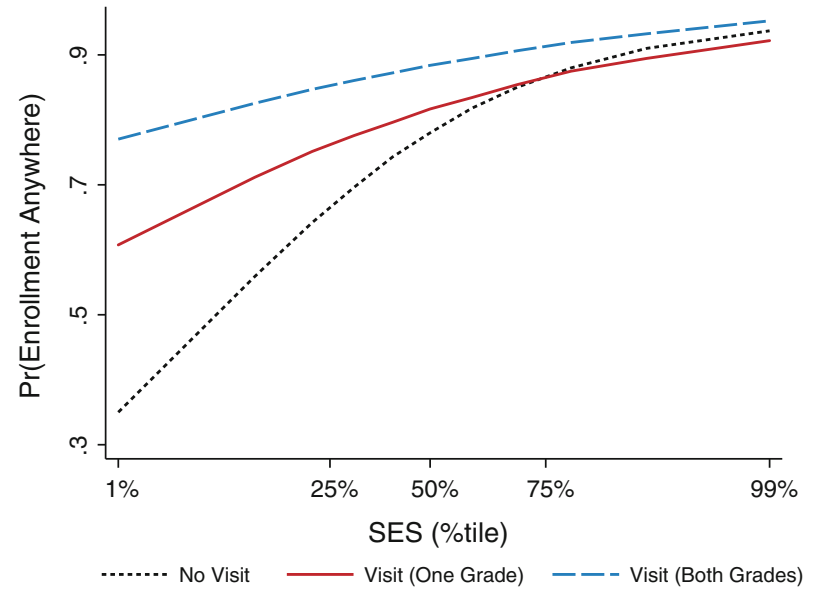

In sum, Figs. 2 and 3 indicate that variation in the effects of counseling by socioeconomic status revolved around college attendance in general, rather than enrollment at a specific institutional level. In other words, Figs. 2 and 3 suggest that school-based college counseling did improve the probability of four-year enrollment among low-SES populations, but that unique benefits accrued only with respect to whether low-SES students enrolled in postsecondary education, and not where they enrolled.

\section{Discussion}

Meaningfully and substantially improving college participation in the United States will likely require that more low-SES students pursue higher education (Lee et al. 2011) - it is these students on which the United States' continued prosperity and competitiveness may depend, and it is within this demographic where the most gains are to be made. However, students from low socioeconomic backgrounds often times lack not only the resrources, but the information and support needed to enroll and succeed in postsecondary education (McDonough 2005; Tierney and Venegas 2009). More often than not, they live in homes, reside in communities, and attend schools where college-going is not the norm and where few adults, let alone adult educators, understand the prerequisites to, and benefits of, a postsecondary education. Consequently, many academically capable, yet disadvantaged students continue to bypass college, while many policymakers continue to lament disparities in college enrollment, as well as the impending shortage of college-educated workers in this country.

As indicated previously, this study aimed to examine the relationship between schoolbased college counseling and the likelihood of postsecondary enrollment, and to determine whether the effects of such counseling varied across socioeconomic groups. Encouragingly, my analysis revealed school-based counseling as making a distinct and substantial contribution to the college enrollment and destinations of low-SES populations especially. Moreover, it suggests that committing additional time and resources to the provision of school-based college counseling may narrow the college participation gap-in particular, by improving enrollment rates among low-SES students, and by moving higher proportions of low-SES students to enroll in four-year institutions, where their prospects for degree completion are comparatively higher (Doyle 2009; Long 2009). 
More broadly, this study also adds to a growing body of research supporting the important relationship between school personnel, disadvantaged students, and postsecondary choice (Engberg and Wolniak 2010; McDonough 1997; Perna 2006)—identifying school counselors as a central and potentially indispensable link in the college-going process for low-SES populations and to which low-SES students may connect for college guidance. Furthermore, it reaffirms what theories of human and social capital intimate: that when given the time and opportunity, school counselors can connect low-SES and other disadvantaged students to the individuals and resources needed for college transition (Kim and Schneider 2005; Plank and Jordan 2001).

In their role as educator, academic advisor, and intermediary between secondary and postsecondary institutions, school counselors are uniquely situated to guide students through an increasingly complex college application process (Bryan et al. 2011), as this study suggests; however, in order to actually "bridge" low-SES students to postsecondary education, and especially to institutions that are commensurate with their credentials and talents, school counselors must be able to effectively and sufficiently engage in postsecondary planning.

Unfortunately, there is a growing body of evidence suggesting that counselors possess neither time nor the skills needed to adequately facilitate college transition, especially for low-SES students. While low-SES students are more reliant on high school personnel for college-related information (A. Cabrera and La Nasa 2001; Tomas Rivera Policy Institute 2004), they are less likely to have access to a counselor who is available and prepared to assist in college-related matters (Perna et al. 2008). Often compelled to address the "more immediate" needs of their students - which can include needs related to standardized testing, dropout prevention, mental health, sexual health, substance abuse, and domestic violence, among others-many "low-SES" counselors can no longer provide adequate college guidance (Venezia and Kirst 2005), and are increasingly divesting themselves of college admissions counseling (Clinedinst et al. 2011; Rosenbaum et al. 1996; Perna and Thomas 2009).

The move away from college counseling, although pervasive in low-SES high schools, is becoming the norm in more advantaged settings too, and is largely due to the increasingly manifold and ambiguous role of the school counselor (McDonough 2005). Over the past several decades, and as the administrative responsibilities of school have expanded, counselors have been assigned to more job duties that are unrelated to their training and intended purpose (American School Counslor Association 2005), such as scheduling, proctoring, hall monitoring and various discipline-related tasks (Beesley 2004; Leuwerke, Walker, and Shi 2009) — a trend that many believe will continue, given that counselors have not sufficiently demonstrated their professional impact (Baker 2001; Beesley 2004; House and Hayes 2002).

In response to the curtailment of school-based college counseling, more advantaged students have sought "outside" assistance, and have increasingly relied on a burgeoning industry of private counselors to secure their place in the most selective and affluent tiers of an increasingly stratified postsecondary system (Espenshade and Radford 2009; McDonough et al. 1997). Consequently, gaps in college-related information, resources and support are being compounded, as are the disadvantages that low-SES students face with respect to their educational and professional advancement.

Regrettably, neither educators nor policymakers have given much priority to addressing these disparities, or to improving the training and availability of school-based college counselors. Currently, only $25 \%$ of high schools require their counselors to complete professional development in college advising (Clinedinst et al. 2011), while less than $10 \%$ of 
counselor education/training programs offer coursework or practica devoted to college admissions and/or financial aid advising (National Association of College Admission Counseling 2004; Savitz-Romero 2012). At present, the condition of school counselors and college guidance in America's high schools is not an issue of importance on any major policy agenda, and is consistently absent from national- and state-level discussions on education reform (Bridgeland and Bruce 2011; McDonough 2005). Only California has recently committed to the expansion of school counseling services, and that was to reduce outrageously high student-to-counselor ratios within the state (960-to-1, on average). In 2006, California legislators allocated 200 million dollars to the establishment of the Middle and High School Supplemental School Counseling Program (MHSSCP) — an initiative that was aimed at improving college and career guidance specifically, and which resulted in a $10 \%$ increase in the number of students applying to postsecondary institutions (Rowell et al. 2008). Since MHSSCP, no other states have attempted to expand school counseling services.

The lack of legislative attention devoted to school-based college counseling may stem from the fact that, as mentioned previously, research has not adequately established the effectiveness of school counselors (Dahir and Stone 2009; Gysbers 2004), and in particular, their ability to aid the postsecondary planning of students (Bryan et al. 2011). Moreover, while research has demonstrated that increased educational attainment among low-SES populations is integral to sustained growth and competitiveness (Matthews 2012; Nichols 2011), there has been a lack of empirical evidence supporting a positive relationship between school-based college counseling and the college participation of low-SES students in particular-until now. The results highlighted above suggest that counselors can improve the postsecondary prospects of this underserved student population, perhaps in spite of their current job role. Ideally, this study will give policymakers impetus to increase the number of school-based college counselors and/or provide school-based college counselors with the training and flexibility they need to adequately engage in postsecondary planning.

Equally important is the hope that this study encourages further research on how schools can more competently and more effectively advise students on the college admissions and financial aid processes. While this study was able to uncover the potential benefits of counseling in general, the variables and data on which it relies prevent analysis of what elements of a counselor's background, and what advising activities in particular, have the greatest influence on postsecondary enrollment. As such, recommendations for future research include quantitatively and/or qualitatively exploring how school counselors encourage college enrollment and choice, as well as assessing the "college knowledge" and professional development needs of school-based counselors-who, for better or worse, are the professionals currently and primarily responsible for facilitating postsecondary transition.

Acknowledgments This research was supported by a grant from the American Educational Research Association which receives funds for its "AERA Grants Program" from the National Science Foundation under Grant \#DRL-0941014. Opinions reflect those of the author and do not necessarily reflect those of the granting agencies. The author gratefully acknowledges the support and suggestions of James Hearn, Erik Ness, Manuel González Canché, Sheila Slaughter, Michael Trivette, the editor, anonymous reviewers and the Abington School District (PA).

\section{References}

Adelman, C. (2006). The toolbox revisited: Paths to degree completion from high school through college. Washington, DC: U.S. Department of Education.

Allison, P. (2000). Multiple imputation for missing data: A cautionary tale. Sociological Methods and Research, 28(3), 301-309. 
Allison, P. (2002). Missing data. Thousand Oaks, CA: Sage.

Allison, P. (2012). Handling missing data by maximum likelihood. Haverford, PA: Sage. (Presented at the SAS Global Forum).

Alon, S., \& Tienda, M. (2007). Diversity, opportunity and the shifting meritocracy in higher education. American Sociological Review, 78(4), 294-315.

American School Counslor Association. (2005). The ASCA National Model: A Framework for School Counseling Programs. Alexandria, VA.

Attewell, P., \& Domina, T. (2008). Raising the bar: Curricular intensity and academic performance. Educational Evaluation and Policy Analysis, 30(1), 51-71.

Aud, S., KewalRamani, A., \& Frolich, L. (2011). America's youth: Transitions into adulthood (NCES 2012-026). Washington, DC: U.S. Department of Education, National Center for Education Statistics.

Avery, C., \& Kane, T. J. (2004). Student perceptions of college opportunities. The Boston COACH program. In C. Hoxby (Ed.), College choices: The economics of where to go, when to go, and how to pay for it (pp. 355-394). University of Chicago Press.

Baker, S. (2001). Reflections on forty years in the school counseling profession: Is the glass half full or half empty? Professional School Counseling, 5(2), 75-83.

Baraldi, A., \& Enders, C. (2010). An introduction to modern missing data analyses. Journal of School Psychology, 48(1), 5-37.

Battistin, E., \& Chesher, A. (2004). The impact of measurement error on evaluation methods based on strong ignorability. London: Institute for Fiscal Studies.

Beattie, I. (2002). Are all adolescent econometricians created equal? Racial, class, and gender differences in college enrollment. Sociology of Education, 75(1), 19-43.

Becker, G. (1993). Human capital: A theoretical and empirical analysis, with special reference to education. Chicago, IL: University of Chicago Press.

Beesley, D. (2004). Teachers' perceptions of school counselor effectiveness: Collaborating for student success. Education, 125(2), 259.

Bettinger, E., Long, B., Oreopoulos, P., \& Sanbonmatsu, L. (2009). The role of simplification and information in college decisions: Results from the H\&R Block FAFSA experiment (NBER Working Paper No. 15361). Cambridge, MA: National Bureau of Economic Research.

Blackwell, M., Iacus, S., King, G., \& Porro, G. (2009). cem: Coarsened exact matching in stata. Stata Journal, 9(4), 524-546.

Bourdieu, P., \& Passeron, J. (1977). Reproduction in education, society and culture. London: Sage Publications.

Bourdieu, P., \& Wacquant, L. (1992). An invitation to reflexive sociology. Chicago: University of Chicago Press.

Bozick, R., \& DeLuca, S. (2005). Better late than never? Delayed enrollment in the high school to college transition. Social Forces, 84, 531-554.

Bridgeland, J., \& Bruce, M. (2011). 2011 National Survey of School Counselors: Counseling at a Crossroads. Washington, DC: The College Board National Office for School Counselor Advocacy.

Brown, D., \& Trusty, J. (2005). School counselors, comprehensive school counseling programs, and academic achievement: Are school counselors promising more than they can deliver?. Professional School Counseling, 9(1), 1-8.

Bryan, J., Holcomb, C., Moore, C., \& Day, N. (2011). School counselors as social capital: The effects of high school college counseling on college application rates. Journal of Counseling and Development, 89, 190-199.

Cabrera, A. (1994). Logistic regression analysis in higher education: An applied perspective. In J. C. Smart (Ed.), Higher education: Handbook of theory and research (Vol. 10, pp. 225-256). New York: Agathon Press.

Cabrera, A., \& La Nasa, S. (2001). On the path to college: Three critical tasks facing America's disadvantaged. Research in Higher Education, 42(2), 119-149.

Carnevale, A., \& Strohl, J. (2010). How increasing access is increasing inequality in postsecondary education. In R. Kahlenberg (Ed.), Rewarding the Strivers: Helping Low Income Students Succeed In College (pp. 225-256). New York: Century Foundation.

Catsiapis, G. (1987). A model of educaional investment decisions. Review of Economics and Statistics, 69, 33-41.

Cheng, S., \& Long, J. (2007). Testing for IIA in the multinomial logit model. Sociological Methods \& Research, 35(4), 583-600.

Choy, S. (2001). Students whose parents did not go to college: Postsecondary access, persistence, and attainment (NCES 2001-126). Washington, DC: U.S. Department of Education. 
Clinedinst, M., Hurley, S., \& Hawkins, D. (2011). State of college admission 2011. Washington, DC: National Association for College Admission.

Coleman, J., \& Hoffer, T. (1987). Public and private high schools: The impact of communities. New York, NY: Basic Books.

Coleman, J. C. (1988). Social capital in the creation of human capital. American Journal of Sociology, 94, 95-120.

Conley, D. (2005). College knowledge: What it really takes for students to succeed and what we can do to get them ready. San Francisco: Jossey-Bass.

Dahir, C. (2004). Supporting a nation of learners: The role of school counseling in educational reform. Journal of Counseling \& Development, 82(3), 344-353.

Deil-Amen, R. \& Tevis, T.L. (2010). Circumscribed agency: The relevance of standardized college entrance exams for low-SES high school students. The Review of Higher Education, 33(2), 141-175.

DesJardins, S., \& Toutkoushian, R. (2005). Are students really rational? The development of rational thought and its application to student choice. In J. C. Smart (Ed.), Higher Education: Handbook of Theory and Research (Vol. 20, pp. 191-240). Dordrecht, The Netherlands: Kluwer Academic Publishers.

Doyle, W. (2009). The effect of community college enrollment on bachelor's degree completion. Economics of Education Review, 28(2), 199-206.

Eccles, J., Vida, M., \& Barber, B. (2004). The relation of early adolescents' college plans and both academic ability and task value beliefs to subsequent college enrollment. Journal of Early Adolescence, 24, 63-77.

Elwood, D., \& Kane, T. (2000). Who is getting a college education? Family background and growing gaps in enrollment. In S. Danziger \& J. Waldfogel (Eds.), Securing the Future (pp. 283-324). New York: Russel Sage Foundation.

Enders, C. (2001). The impact of nonnormality of full information maximum likelihood estimation for structural equation models with missing data. Psychological Methods, 6(4), 352-370.

Enders, C. (2010). Applied missing data analysis. New York: The Guilford Press.

Engberg, M., \& Wolniak, G. (2010). Examining the effects of high school context on postsecondary enrollment. Research in Higher Education, 51(2), 132-153.

Espenshade, T., \& Radford, A. (2009). No longer separate, not yet equal: Race and class in elite college admission and campus life. Princeton, NJ: Princeton University Press.

Freeman, K. (1997). Increasing African Americans participation in higher education: African American high school student perspectives. Journal of Higher Education, 68(5), 523-550.

Glick, J., \& White, M. (2004). Postsecondary school participation of immigrant and native youth: The role of familial resources and educational expectations. Social Science Research, 33(2), 272-299.

Goldrick-Rab, S. (2006). Following their every move: How social class shapes postsecondary pathways. Sociology of Education, 79, 61-79.

Granovetter, M. (1973). The strength of the weak ties. American Journal of Sociology, 78, 1360-1380.

Granovetter, M. (1983). The strength of the Weak Ties: Revisited. Sociological Theory, 1, 201-233.

Greene, W. (2011). Econometric analysis (7th edition). Upper Saddle River, NJ: Prentice Hall.

Grodsky, E. \& Jones, M.T. (2004). Real and imagined barriers to college entry: Perceptions of Cost. Social Science Research, 36, 645-766.

Gysbers, N. (2004). Comprehensive guidance and counseling programs: The evolution of accountability. Professional School Counseling, 8, 1-14.

Hausman, J., \& McFadden, D. (1984). Specification tests for the multinomial logit model. Econometrica: Journal of the Econometric Society, 52(5), 1219-1240.

Hearn, J. (1991). Academic and nonacademic influences on the college destinations of 1980 high school graduates. Sociology of Education, 63(4), 158-171.

Heller, D. (1999). The Effects of Tuition and State Financial Aid on Public College Enrollment. The Review of Higher Education, 23, 65-89.

Hill, L. (2008). School strategies and the 'college-linking' process: Reconsidering the effects of high schools on college enrollment. Sociology of Education, 81(1), 53-76.

Holcomb-McCoy, C. (2010). Involving low-income parents of color in college-readines activities: An exploratory study. Professional School Counseling, 14(1), 115-124.

Horn, L., Chen, X., \& Chapman, C. (2003). Getting ready to pay for college: What students and their parents know about the cost of college tuition and what they are doing to find out. Washington, DC: US Department of Education.

Horvat, E. (2001). Understanding equity and access in higher education: The potential contribution of Pierre Bourdieu. In J. C. Smart (Ed.), Higher education: Handbook of theory and research (Vol. 16, pp. 195238). New York: Agathon Press. 
Hosmer, D. W., \& Lemeshow, S. (1989). Applied logistic regression. New York: Wiley.

Hossler, D., \& Gallagher, K. (1987). Studying student college choice: A three-phase model and the implications for policymakers. College and University, 62(3), 207-221.

Hossler, D., Schmit, J., \& Vesper, N. (1999). Going to college: How social, economic, and educational factors influence the decisions students make. Baltimore, MD: Johns Hopkins University Press.

House, R., \& Hayes, R. (2002). School counselors: Becoming key players in school reform. Professional School Counseling, 5(4), 249-56.

Iacus, S., \& King, G. (2012). How coarsening simplifies matching-based causal inference theory. (Working Paper (available at http://gking.harvard.edu/publications)).

Iacus, S., King, G., \& Porro, G. (2011). Multivariate matching methods that are monotonic imbalance bounding. Journal of the American Statistical Association, 106(493), 345361.

Iacus, S., King, G., \& Porro, G. (2012). Causal inference without balance checking: Coarsened exact matching. Journal of Political Analysis, 120(1), 1-24.

Kim, D., \& Schneider, B. (2005). Social capital in action: Alignment of parental support in adolescents' transition to postsecondary education. Social Forces, 84(2), 1181-1206.

King, J. (1996). The decision to go to college. Attitudes and experiences associated with college attendance among low-income students. New York: The College Board.

Lamont, M., \& Lareau, A. (1988). Cultural capital: Allusions, gaps and glissandos in recent theoretical developments. Sociological Theory, 6(2), 153-168.

Lapan, R., Gysbers, N., \& Sun, Y. (1997). The impact of more fully implemented guidance programs on the school experiences of high school students: A statewide evaluation study. Journal of Counseling and Development, 75(4), 292-302.

Lee, J., Edwards, K., Menson, R., \& Rawls, A. (2011). The college completion agenda: 2011 Progress report. New York: The College Board.

Leuwerke, W., Walker, J., \& Shi, Q. (2009). Informing principals: The impact of different types of information on principals' perceptions of professional school counselors. Professional School Counseling, 12(4), 263-271.

Lin, N. (2001). Social Capital: A Theory of Social Structure and Action. New York, NY: Cambridge University Press.

Long, J. S. (1997). Regression models for categorical and limited dependent variables (Vol. 7). London: Sage Publications, Inc.

Long, J., \& Freese, J. (2006). Regression models for categorical and limited dependent variables using Stata. College Station, TX: Stata Press.

Long, B., \& Kurlaender, M. (2009). Do community colleges provide a viable pathway to a baccalaureate degree?. Educational Evaluation and Policy Analysis, 31(1), 30-53.

Luke, D. (2004). Multilevel modeling. Thousand Oaks, CA: Sage.

Luna De La Rosa, M. (2006). Is opportunity knocking?: Low income students' perceptions of college and financial aid. American Behavioral Scientist, 49(12), 1670-1686.

Martinez, M., \& Klopott, S. (2005). The link between high school reform and college access for low-income and minority youth. Washington, DC: American Youth Policy Forum and Pathways to College Network.

Matthews, D. (2012). A stronger nation through higher education: How and why Americans must meet a big goal for college attainment. Indianapolis, IN: Lumina Foundation for Education.

McDonough, P. (1997). Choosing colleges. How social class and schools structure opportunity. Albany, NY: State University of New York Press.

McDonough, P. (2005). Counseling and college counseling in America's high schools. Alexandria, VA: National Association for College Admissions Counseling.

McDonough, P., Korn, J., \& Yamasaki, E. (1997). Access, equity, and the privatization of college counseling. The Review of Higher Education, 20(3), 297-317.

McFadden, D. (1973). Conditional logit analysis of qualitative choice behavior. In P. Zarembka (Ed.), Frontiers in Econometrics (pp. 105-142). New York: Academic Press.

Muhammad, C. (2008). African American students and college choice: A consideration of the role of school counselors. NASSP Bulletin, 92(2), 81-94.

National Association of College Admissions Counseling. (2004). Findings of the Ad Hoc Committee on Graduate Coursework. Arlington, VA.

Nichols, A. H. (2011). Developing the 20/20 vision on the 2020 degree attainment goal: The threat of income-based inequality in education. Washington, DC: Pell Institute for the Study of Opportunity in Higher Education.

Panter, A., \& Sterba, S. (2011). Handbook of ethics in quantitative methodology. New York: Routledge. 
Paulsen, M. (2001). The economics of human capital and investment in higher education. In M. Paulsen \& J. Smart (Eds.), The finance of higher education: Theory, research, policy and practice. (pp. 55-94). New York: Agathon Press.

Paulsen, M., \& St. John, E. (2002). Social class and college costs: Examining the financial nexus between college choice and persistence. Journal of Higher Education, 73(3).

Perna, L. (2004). Impact of student aid program design, operations, and marketing on the formation of family college-going plans and resulting college-going behaviors of potential students. Boston: The Education Resources Institute, Inc. (TERI).

Perna, L. (2006). Studying college choice: A proposed conceptual model. In J. C. Smart (Ed.), Higher education: Handbook of theory and research (Vol. 21, pp. 99-157). Boston: Kluwer Academic Publishers.

Perna, L., Rowan-Kenyon, H., Bell, A., Thomas, S., \& Li, C. (2008). A typology of federal and state programs designed to promote college enrollment. The Journal of Higher Education, 79(3), 243-267.

Perna, L., \& Thomas, S. (2009). Barriers to college opportunity the unintended consequences of statemandated testing. Educational Policy, 23(3), 451-479.

Perna, L., \& Titus, M. A. (2005). The relationship between parental involvement as social capital and college enrollment: An examination of racial/ethnic group differences. Journal of Higher Education, 76(5), 485-518.

Peugh, J., \& Enders, C. (2004). Missing data in educational research: A review of reporting practices and suggestions for improvement. Review of educational research, 74(4), 525-556.

Plank, S., \& Jordan, W. (2001). Effects of information, guidance, and actions on postsecondary destinations: A study of talent loss. American Education Research Journal, 38, 947-979.

Rabe-Hesketh, S., \& Skrondal, A. (2006). Multilevel modeling of complex survey data. Journal of the Royal Statistical Society, 169, 805-827.

Raudenbush, S. W., \& Bryk, A. S. (2002). Hierarchical linear models: Applications and data analysis methods. Newbury Park, CA: Sage.

Raykov, T., \& Marcoulides, G. (2008). An introduction to applied multivariate analysis. New York: Routledge.

Raykov, T., \& Marcoulides, G. A. (2010). Introduction to psychometric theory. New York: Taylor \& Francis.

Roderick, M., Nagaoka, J., Coca, J., \& Moeller, E. (2009). From high school to the future: Making hard work pay off. Chicago, IL: Consortium on Chicago School Research.

Roodman, D. (2011). Fitting fully observed recursive mixed process models with cmp. The Stata Journal, 11(2), 159-206.

Rosenbaum, J., Miller, S., \& Krei, M. (1996). Gatekeepers in the era of more open gates. American Journal of Education, 104, 257-279.

Rowan-Kenyon, H., Bell, A., \& Perna, L. (2008). Contextual influences on parental involvement in college going: Variations by socioeconomic status. The Journal of Higher Education, 79(5), 564-586.

Rowan-Kenyon, H., Perna, L., \& Swan, A. (2011). Stucturing Opportunity: The role of school context in shaping high school students' occupational aspirations. The Career Development Quarterly, 59, 330-344.

Rowell, L., Whitson, L., \& Thomas, S. (2008). Middle and high school supplemental counseling program: Increased support for student success in California schools. San Diego, CA: California Association of School Counselors and the Center for Student Support Systems.

Rubin, D. (1996). Multpile imputation after 18+ years. Journal of the American Statistical Association, 91, $473-489$.

Rubin, D. (2006). Matched sampling for causal effects. Cambridge, UK: Cambridge University Press.

Savitz-Romer, M. (2012). Professional college knowledge: Re-envisioning how we prepare our college readiness workforce. Arlington, VA: National Association for College Admission Counseling.

Schafer, J., \& Graham, J. (2002). Missing data: Our view of the state of the art. Psychological Methods, 7(2), $147-177$.

Small, K., \& Hsiao, C. (1985). Multinomial logit specification tests. International Economic Review, 26(3), 619-627.

Stanton-Salazar, R., \& Dornbusch, S. (1995). Social capital and the reproduction of inequality: Information networks among mexican-origin high school students. Sociology of Education, 68, 116-135.

St. John, E. (2003). Refinancing the college dream: Access, equal opportunity, and justice for taxpayers. Baltimore, MD: The Johns Hopkins University Press.

Thomas, S., \& Heck, R. H. (2001). Analysis of large-scale secondary data in higher education research: Potential perils associated with complex sampling designs. Research in Higher Education, 42(5), $517-540$. 
Thomas, S., \& Perna, L. (2004). The opportunity agenda: A reexamination of postsecondary reward and opportunity. In J. C. Smart (Ed.), Higher education: Handbook of theory and research (Vol. 19, pp. 43-84). Boston: Kluwer Academic Publishers.

Tierney, W., \& Venegas, K. (2009). Finding money on the table: Information, financial aid, and access to college. Journal of Higher Education, 80(4), 363-388.

Tomas Rivera Policy Institute. (2004). Caught in the financial aid information divide: A national survey of Latino perspectives on financial aid. Reston, VA: The Sallie Mae Fund.

Treiman, D. J. (2009). Quantitative data analysis: Doing social research to test ideas (Vol. 27). San Francisco, CA: Jossey-Bass.

Turley, R. N. (2009). College proximity: Mapping access to opportunity. Sociology of Education, 82(2), $126-146$.

Venezia, A., Kirst, M., \& Antonio, A. (2003). Betraying the Dream: How Disconnected K-12 and Postsecondary Education Systems Undermine Student Aspirations. Palo Alto, CA: Stanford University.

Venezia, A., \& Kirst, M. W. (2005). Inequitable opportunities: How current education systems and policies undermine the chances for student persistence and success in college. Educational Policy, 19(2), 283-307.

Walpole, M. (2003). Socioeconomic status and college: How SES affects college experiences and outcomes. Review of Higher Education, 27, 45-73.

White, H. (1980). Using least squares to approximate unknown regression functions. International Economic Review, 21(1), 149-170.

Zeldin, A., Britner, S., \& Pajares, F. (2008). A comparative study of the self-efficacy beliefs of successful men and women in mathematics, science and technology careers. Journal of Research in Science Teaching, 45, 1036-1058.

Zelkowski, J. (2010). Secondary mathematics: Four credits, block schedules, continuous enrollment? What maximizes college rseadiness?. The Mathematics Educator, 20(1), 8-21. 